\title{
The Study of Monetary Policy Instruments and Implementation Challenge in Laos
}

\author{
Maliny Sourigna ${ }^{1}$, Shuzhen $\mathrm{Zhu}^{1} \&$ Atsara Chanthavieng ${ }^{2}$ \\ ${ }^{1}$ Glorious Sun School of Business and Management, Donghua University, Shanghai, China \\ ${ }^{2}$ College of Economic and Management, Guangxi Normal University, Guangxi Zhuang Autonomous Region, \\ China \\ Correspondence: Maliny Sourigna, Glorious Sun School of Business and Management, Donghua University, \\ 1882 Yan'an West Road, Changning District, 200051, Shanghai, China. Tel: 86-150-0095-5150. E-mail: \\ nq0090@yahoo.com
}

Received: December 6, 2017

Accepted: January 29, 2018

Online Published: January 30, 2018

doi:10.5539/ijef.v10n2p169

URL: https://doi.org/10.5539/ijef.v10n2p169

\begin{abstract}
The monetary policies have been developed and implemented by the Bank of Lao PDR (BOL). This article presents the monetary policy framework in Laos which includes the policy instruments and implementation mechanism. The author applied the actual implementation and the existing theories to display the Lao monetary tools such as interest rate, open market operation, reserve ratio, exchange rate, credit control, cash flow management and relevant regulations. As well as the policy implementation mechanism has been presented in policy decision, operation department and operation mechanism.

The author applies the descriptive analysis on the monetary policy implementation challenge and addressing. They based on monetary policy theories, literature studied, and practical experience from the operation authority. The analysis has found the challenges as The limited of market operation; the dollarization and multiples currencies consumer preference; the challenge in Kip prices, and Kip lending; the foreign capital outflow. Then, the analysis moved forward to the challenge addressing. All of these measures are taken to maintain the efficient management of the monetary system, ensure an effectiveness of the monetary policy implementation in the long-term.
\end{abstract}

Keywords: Laos, monetary policy instrument, implementation mechanism, challenge

\section{Introductions}

After the war ended in December 1975, the economics of the country had been rehabilitated to operat the central plan economy system for socialism. In 1976, the liberating Kip currency was released. The National bank was a central bank which unified the Viengxay central bank and the national bank under the revolutionary government. This bank took the responsibility for managed the printing, circulation, ensuring the stability of the currencies, and made efforts to mobilize funds to support the economic rehabilitation. Meanwhile, the raising funds allowed the increased provision of loans for an agricultural, industrial and domestic trade of commodity (Keomanisy, 2003). In 1980, the National Bank's Kip currencies replaced the liberated Kip and were circulated as national currency until now.

During 1986-1988, the Government of Lao PDR and Party implemented a New Economic Mechanism (NEM) for financial reform. Prior to the implementation of the New Economic Mechanism, the monetary policy framework in Laos was run by direct monetary instruments (Kyopilavong, 2007). New monetary policies developed within the New Economic Mechanism played an important role in micro-economic development, which managed by the central bank in the country. Multiple studies have shown that monetary policies have a significant influence on national GDP growth and inflation rates. Since the implementation of New Economic Mechanisms, authorities in Laos have continuously adapted economic policies to promote the long-term GDP growth of the country.

The Bank of Lao PDR (BOL) is the central bank of the country and acts as a secretariat of the Government of Lao PDR to administer the financial system and guide the implementation of the NEM. The BOL has oversight of currency and financial institutions as well as promoting and supervising capital flow to support economic 
development (BOL Law No.5, 1994). Within this role, the BOL leads the development, monitoring, and adjustment of national monetary policy, while also maintaining a key role in policy implementation. The goals of the $\mathrm{BOL}$ are to maintain a stable Kip price and exchange rate and maintain low inflation rate.

\section{Literature Reviews}

Previous studies have pointed out that Lao monetary policy has been applied by a combination of direct and indirect tools with vague monetary policy channels and objectives (Kyophilavong, 2007). The intervention of exchange rate would offer an effective tool to decrease the trilemma (Steiner, 2015). Manipulations of exchange and interest rates have been efficient instruments of monetary policy in many developing countries, influencing long-term economic growth. The Research of Srithilat (2017) shown that the Lao policy authorities should rely on manipulations of exchange rate and interest rates rather than increase the money supply for promoting economic growth. It is due to the exchange rate and interest rate positively have affected the GDP in long-run. In contrast, the money supply only affects the GDP in short-term does cause the inflation raising.

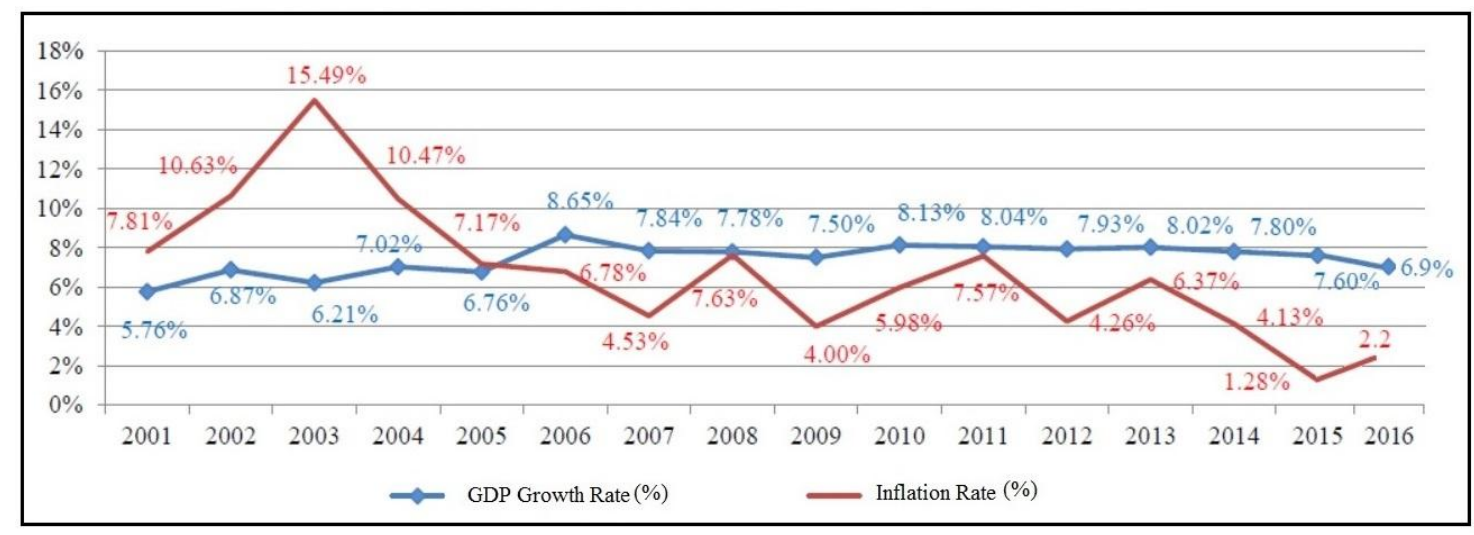

Figure 1. Real GDP growth and inflation rate of Laos in 2001-2016

Source: The Bank of Lao PDR: "Lao economic data".

As the studied of Lacker (2014) confirm that increasing the supply broad money has a negative correlation to GDP growth rate, while contributing to increased inflation rates. Currently, the policy authority in Laos experience the increased or decreased the money supply adjust from the market demand. As known, in recent year, the increasing of the money supply was approximated controlling at 25\% (BOL, 2016).

A cross-country comparative study by Ma and Lin (2016) showed that the financially developed countries, the monetary policies were lower effective to the GDP and declined in controlling the inflation if compared to financially less developed countries. A case study from neighboring Vietnam shows that manipulation of exchange and interest rates will have impacts on inflation rates only in the short-term. While increasing the supply of broad money, for example by increasing credit and lending, has a positive correlation to rising inflation in middle-term, manipulations of interest and exchange rates have a more moderate influence on inflation for two quarters to five quarters. The research of Bhattacharya (2014) shows that manipulation of interest and exchange rates affect inflation, which explains why monetary policies in Vietnam reduced high inflation after the 1980s. The ASEAN countries study shows that competition between banking institutions, signified by lending ratios, size of banks, capitalized and liquidity level, has created a context in which monetary policies can have a more significant impact on domestic GDP growth and economic stability(Khan et al., 2016).

\section{The Lao Monetary Policy Instruments}

According to the institutional and domestic market condition, the authority continuously applies monetary policy tools such as basis interest rate (Kyophilavong, 2007), compulsory reserved rate, open market operations and daily final accounting balance of commercial bank adjustment.

\subsection{Interest Rate and Capital Raising}

Authorities introduce the Ad-Hoc interest rate policy, which is implemented by the commercial bank to lower the cost of Lao Kip lending and promote Kip credit increasing (IMF, 2015). When necessary, adjusting the central bank benchmark interest rate or commercial banks interest rate (Table 1). 
Increasing capital by using positive interest rates is the trend of interest in the region and internationally. To be consistent with this trend of currency management, authorities apply various methods for raising capital from both domestic and foreign sources.

Table 1. The interest rate for deposit and lending of commercial bank (percent per year)

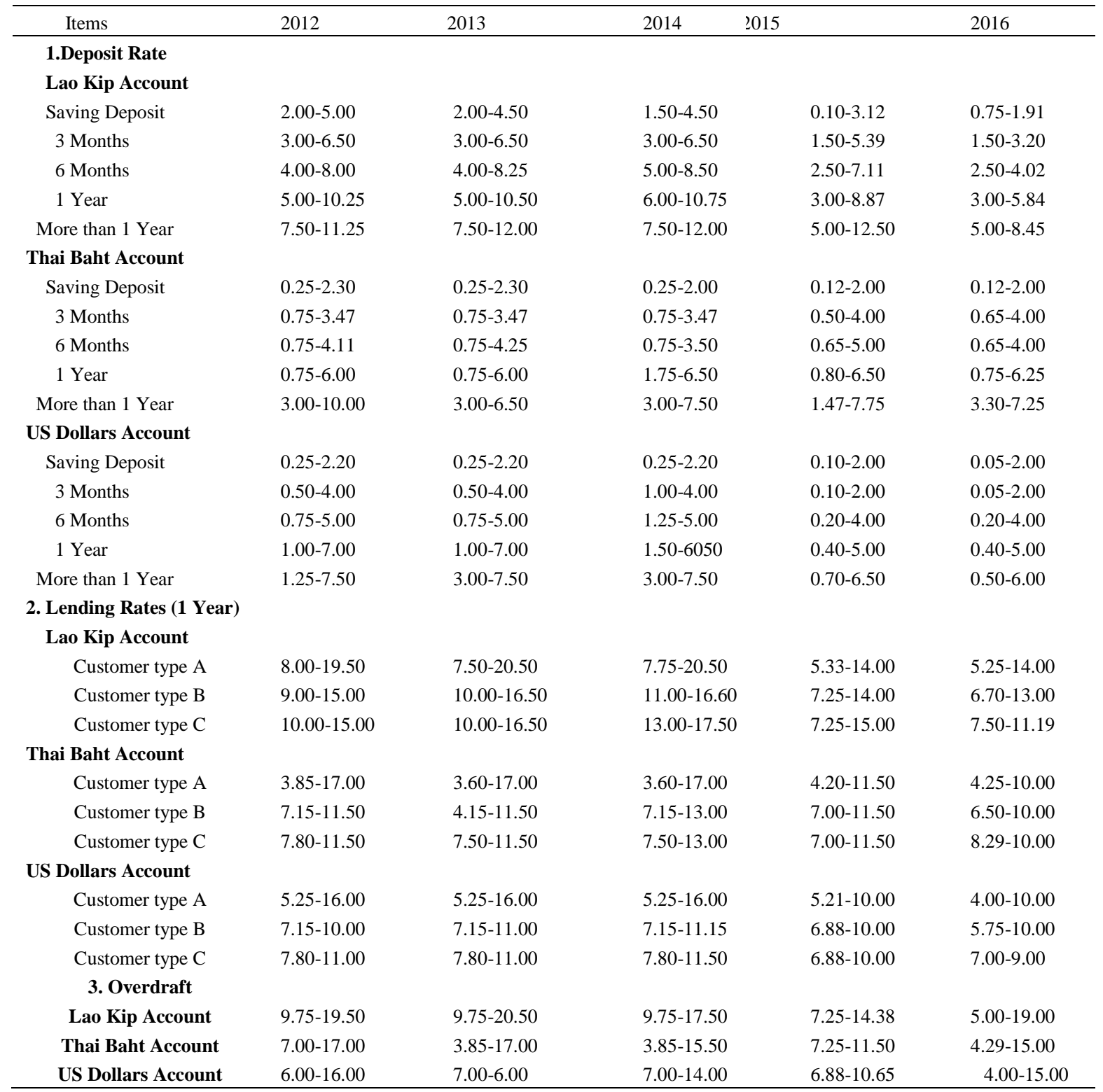

Source: Bank of Laos.

\subsection{Reserve Requirement Ratio}

Authorities continue to set and adjust the reserve requirement rate when necessary by developing tracking base money programs such as the Reserve Money Program (RMP) and the Macroeconomic Simulation System. According to the policy authority indicated, reserve requirement has been implementing by the commercial banks, not include the non-bank financial institutions. The deposit reserve ratio for Kip has been set on 5\%, for foreign currencies fixed at $10 \%$ (BOL, 2016). In recent year, the regulation only changed the ratio of currency and eligible bond. The authority adjusted by increasing the proportion scroll of the eligible bond up to $50 \%$ for LAK reserve and $25 \%$ for foreign currency deposit reserve.

\subsection{Open Market Operation}

To improve liquidity in the financial system, which allowed for additional investment in national development 
programs, authorities played a key role in promoting the issuing, selling, repurchase, and trading of BOL bonds and government bonds(for a term of one year). The BOL operated as the primary market for commercial banks and non-bank financial institutions to purchase or sell BOL bonds and government bonds. At the same time, the BOL developed and implemented the relating regulations to encourage commercial banks and non-bank financial institutions to use BOL and government bonds for inter-bank exchanges.

\subsection{Exchange Rate}

The daily official reference rate is the main instrument for foreign exchange policy to stabilize the monetary value of the national currency. To balance the market rate, the authority applies FX trading in the inter-bank market and money market. Authorities may also apply risk prevention tools on the foreign exchange such as FX SWAPs, Forward Contract, Futures, and Options. Lastly, authorities can apply legal acts on foreign exchange management.

\subsection{Credit Control (Deposit and Lending Ratio)}

Authorities maintain credit levels by keeping a balance of the weighted average lending rate, and deposit rate (see Figure 2), according to the situation of each economic development period.

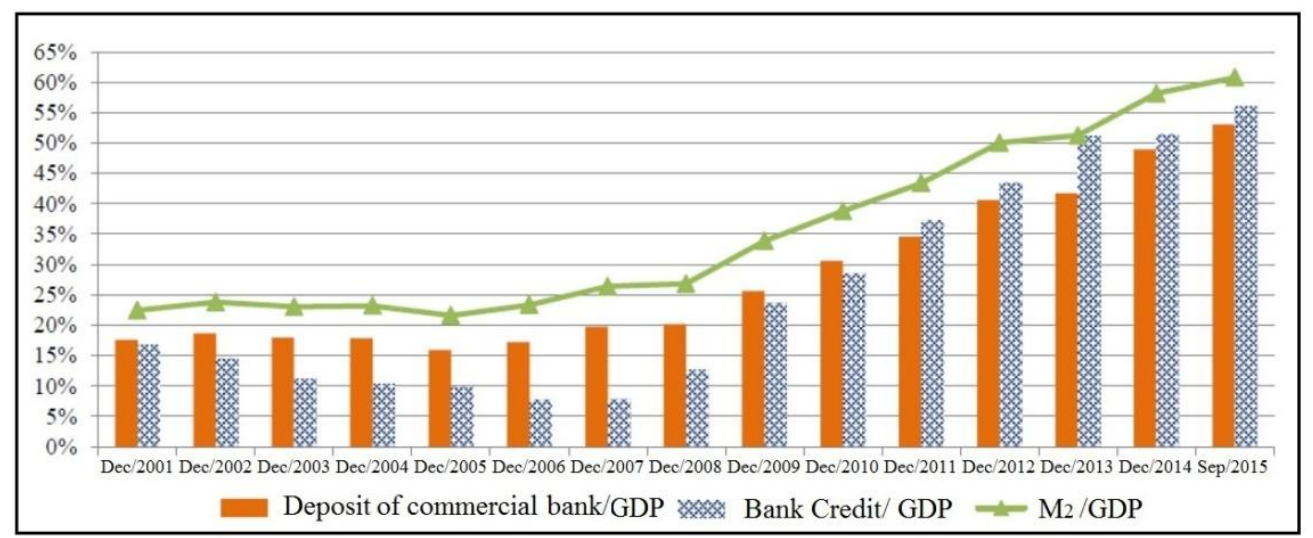

Figure 2. M2 ratio, commercial banks deposit and lending ratio per GDP from Dec/2001- Sep/2015

Source: Bank of Laos.

\subsection{Cash Flow Management}

Authorities apply the International Transaction Reporting System to frequently follow up the cash inflow and outflow. The International Transaction Reporting System also supports authorities to estimate/forecast the quantity of incoming and outgoing cash flow and avoid the impact on leverage and stability of the system (10 Years Strategy of BOL, 2016).

\subsection{Prudential Rule and Regulations}

The BOL actively promulgates and revises prudential rules and regulations required for the robust and sustainable development of the monetary and financial system, specifically in relation to the use of foreign currencies and manipulation of foreign currency exchange rates. The BOL also plays a key role in enforcing the implementation of prudential rules and regulations within financial market, commercial banks, and financial institutions.

\section{Policy Implementation Machanism}

\subsection{Monetary Policy Decision Process}

The Decree Law, No.5 mandates that the BOL takes charge of monetary policy research, design, and implementation, included relating policy such as the interest rate policy and exchange rate policy, to be responsible to propose those policies to the Government for decision and promulgation (Kyophilavong, 2009). In general, the monetary and exchange rate policy was accomplished by the governor of the BOL and approved by the government (see Figure 3). 


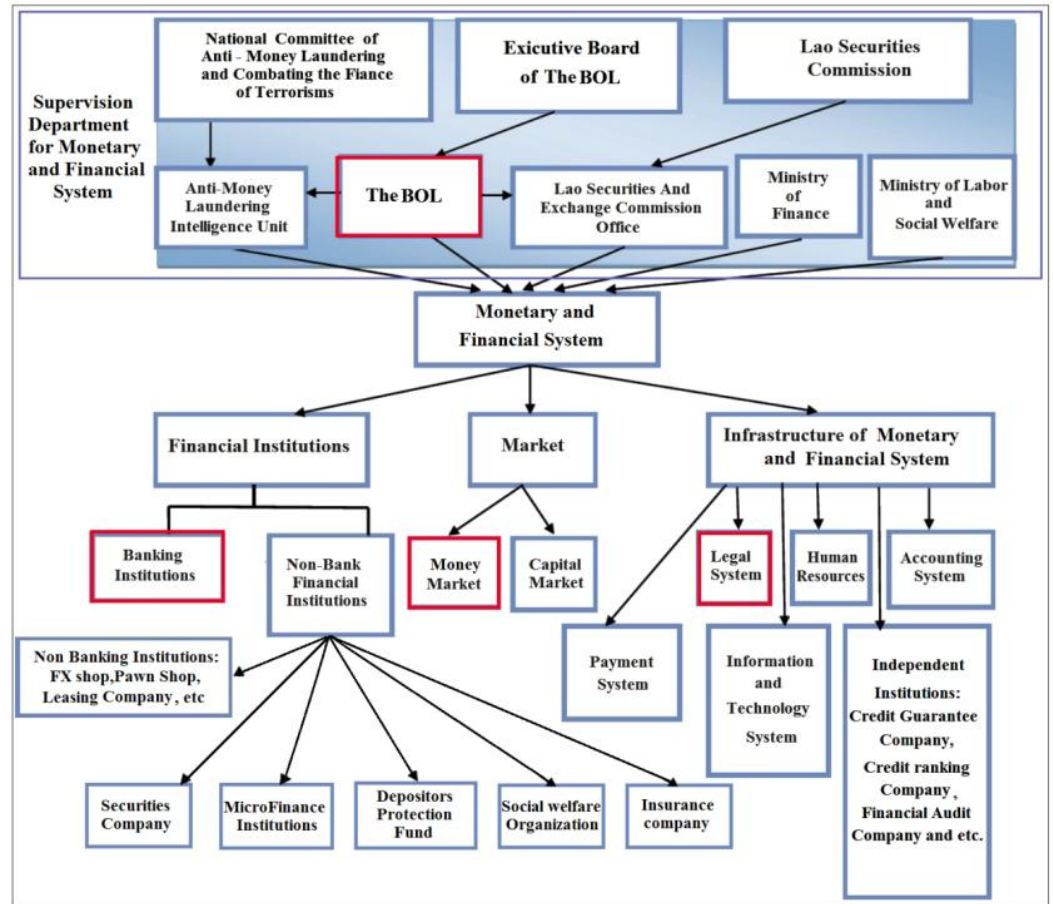

Figure 3. The Structure of Lao monetary and financial system

Source: Bank of Laos.

According to the domestic market situation, the monetary policy applies direct tool such as interest rate implemented by the BOL and Commercial Banks, lending and deposit ratio, and indirect tools including market operation and reserve requirements, which are carried out by the BOL and the executive object is commercial banks. Figure 3 showed that the supervision department and structure of the monetary and financial system. The BOL, banking institutions (except Nayoby bank) and Legal systems (including relevant rules and regulations) are the main components of the monetary policy implementation system. Red boxes indicate those institutions directly linked to the Monetary policy implementation system.

The Monetary Policy Department of the BOL designs, monitors and adjusts the policy tools to achieve operating target, intermediate target and ultimate objective as inflation goal which appears in Figure 4.

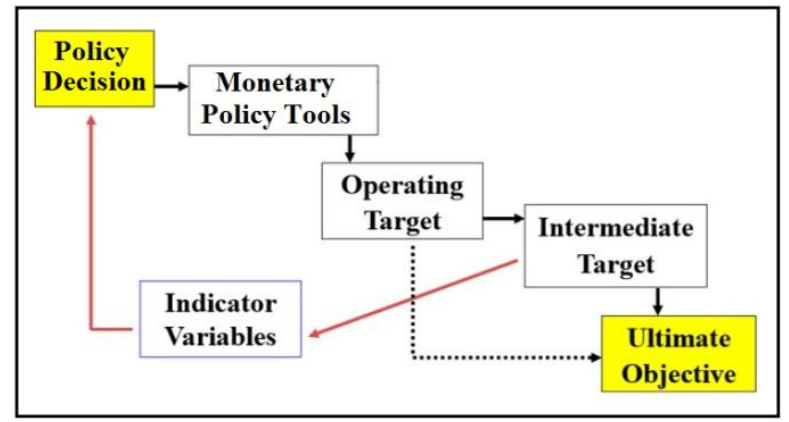

Figure 4. Monetary policy operating process

Source: IMF Training Material.

\subsection{The Monetary Policy Operation Departments}

Within the Bank of Laos, the implementer is the International Financial Market Division, Banking Operation Department (see Figure 5). This division mainly carries out monetary policy implementation to stabilize the monetary system and to be the leader of last resort to solve daily insufficient liquidity problem for commercial banks and financial institutions in Laos. The division's duties include the auction, sale, and management the BOL and Government bonds, operating as the second market for trading, repurchasing of treasuries, monitoring 
deposit reserve and the reserve payment from commercial banks, providing short-term secured loans for banking and financial institutions, supervising the implementation of daily liquidity regulation for commercial banks, and operating and supervising an Inter-bank market program for FX trading. The duties above are implemented both directly and indirectly and influence overall monetary policy effectiveness.

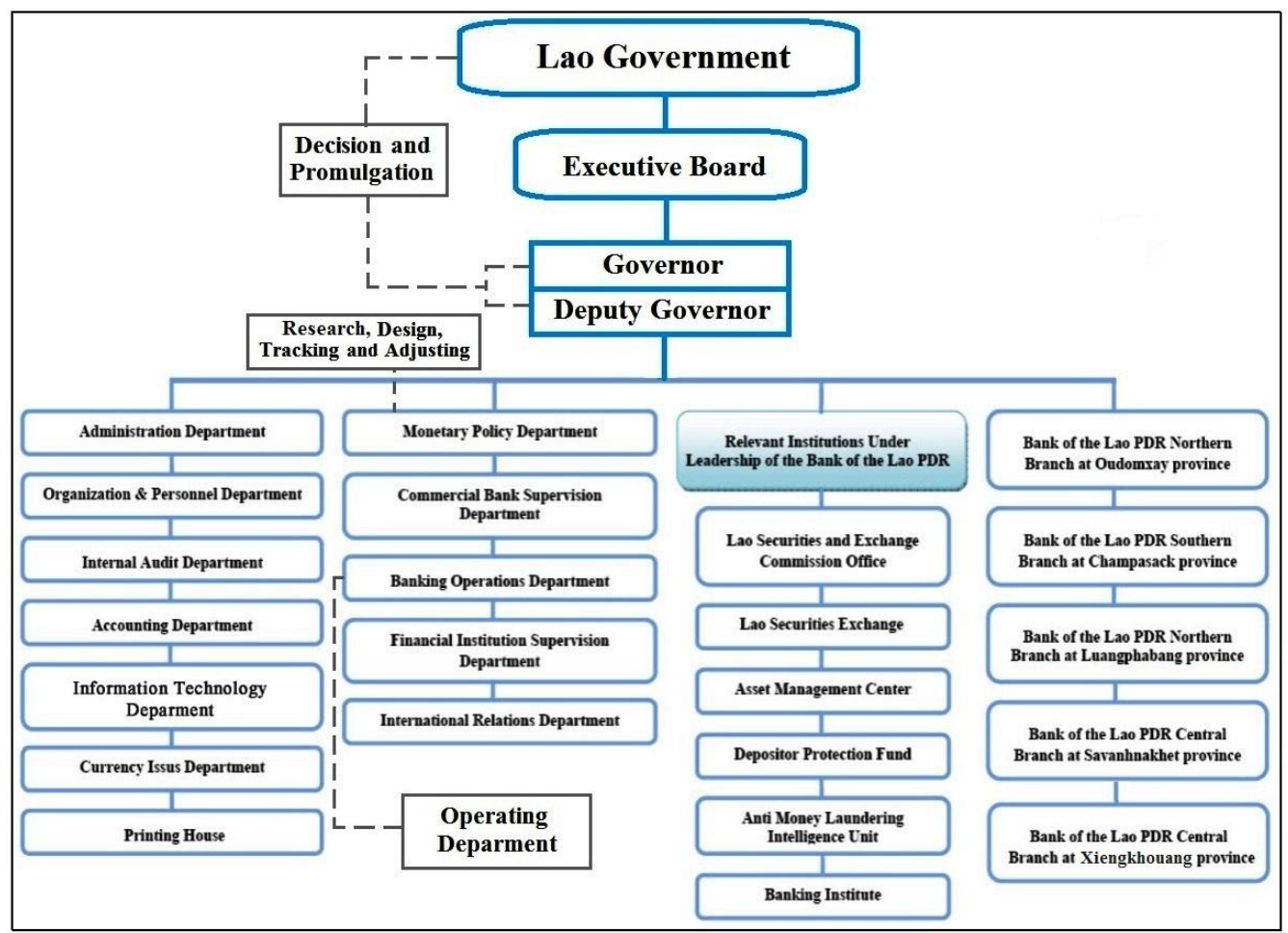

Figure 5. The BOL governance structure and the monetary policy operation

Source: Bank of Laos, Organizational structure of the BOL.

\subsection{Situation of the Monetary Policy Implementation}

To encourage the economic growth, promoting the investment and consumption in the domestic market, maintain the low inflation rate. The policy authority adopted the eased monetary policy integrating the float exchange rate regime to stabilize the LAK price and stimulates the long-term economic steady growth. In recent year, the decrease of the policy interest rate or the short-term secured loan interest rate (Table 2). The commercial bank's deposit interest rate and lending interest rate (Table 1) are also on the declining trend. Those phenomena confirm that the policy authority in Laos implementing the eased monetary policy for long-run.

Table 2. The BOL interest rate

\begin{tabular}{clll}
\hline Year & $<$ Days & $>$ 7 Days & $\mathbf{1 4}$ to $<\mathbf{1 Y e a r}$ \\
\hline 2002 & 20 & 30 & Unset \\
2007 & 12 & 15 & Unset \\
$06 / 02 / 2008$ & 10 & 12.5 & Unset \\
$13 / 05 / 2008$ & 8 & 10 & Unset \\
$17 / 10 / 2008$ & 7 & 8.75 & Unset \\
$07 / 01 / 2009$ & 6 & 7.5 & Unset \\
$13 / 02 / 2009$ & 5 & 6.25 & Unset \\
$07 / 09 / 2009$ & 4 & 5 & Unset \\
$14 / 06 / 2010$ & 4 & 5 & 10 \\
$17 / 09 / 2010$ & 5 & 6.25 & 12.5 \\
$21 / 07 / 2015$ & 4.5 & 5.625 & 11.25 \\
$17 / 08 / 2016$ & 4.25 & 5.31 & 10.63 \\
\hline
\end{tabular}

Source: The BOL Annual Report, BOL Interest Rate. 
Meanwhile, the open market operation is implemented to slow down the too high inflation by the decrease the credit supply to the society. The authority running this instrument by issuing or trading the government bond and The BOL bond. The government bond has been the auction to the commercial banks and financial institutions. Somehow, this type of bond was issued for the financial need of government project. The BOL bond has been issuing in the domestic money market or overseas market. Even the interest of those bonds are as low as the lending interest rate, but the lowest risk and benefit from them still attracted to the buyer. Those two type of bonds can be used for the reserve requirement or the secure loan.

the monetary policy authorities in many countries have implemented the lender of last resort as the combination instrument which synthesized with the open market operation instrument. The central banks all over the world have provided this instrument as the loan convenience type for support the monetary policy implementation. In the different countries has a differ name for this instrument such as The United State Federal Reserve sets this instrument as "Discount Window"; European Union Central Bank conducts it as "Marginal Lending Facility"; The central bank of China "The People Bank of China" and the central bank of Thailand "Bank of Thailand" run them as "Standing Lending Facility or SLF". In Laos, the lender of last resort duty has been implemented by the Banking Operation Department in BOL. It sets up for solving the commercial banks daily insufficient liquidity problem by the short-term secured loan. The authority also applies the financial derivatives such a Swaps, Forward, Futures, and Options Contract. The lender of last resort has been combined implementing with the open market operation, exchange rate policy, policy interest rate, deposit reserve requirement instrument, and the relevant regulations.

The policy authority has introduced the regulations such as "The regulation of maintain the inventory cash for the commercial banks", "The Government Bond auction regulation", "The regulation of maintaining the sufficient of foreign currencies ratio in commercial banks", "The regulation about preserving the reserve requirement for commercial banks", "FX swap interest rate regulation", "discount rate regulation" and etc. Those regulations were issued to support the effectiveness of the monetary policy implementation. In fact, The lender of last resort has been implemented as the indirect instrument for adjusting the credit of commercial banks to affect the money supply to society and be the key for adjusting or maintain the exchange rate in the market.

\section{The Lao Monetary Policy Challenge and Addressing}

\subsection{Understanding the Implementation Challenge}

The policy authority paid close attention to the money market operation, dollarization and foreign currencies consumption problem, exchange rate, Lao Kip value and capital flow. The implementation of those instruments related to the inflation and the economic growth. From the study of the current monetary policy implementation situation. Plussing the research of the existing policy instruments, with knowledge from the BOL plan 2016-2025, The article IV document of IMF, and related literature (Bhattacharya, 2014; Lacker, 2014; Steiner, 2015; Srithilat, 2017). As well as the actual knowledge from the policy implementation department has also been applied to analysis the challenge and addressing. The monetary policy implementation challenge in Laos integrated into four points.

- The limitations of the money market which divided to an inter-bank market and the secondary market for Government bond and the BOL bond. The existing instruments in the market could not satisfy the demand for balance liquidity of commercial bank and enterprises. In Laos, the market operation target accepts of served the monetary policy implementation, also respond to other objectives. In some period, The BOL bond issued mostly in overseas market and Government bond was issued for financial to some government projects.

- The rarely use of risk prevention tools for exchange rate volatility, the risk from external volatility, and pressure on the exchange rate and Kip price in the market. Meanwhile, the high demand for foreign currency in the market caused the over demand of USD lending and Thai Baht landing, which could be harmful to the Kip price stabilizing.

- The dollarization, preference of multi-currency payment and lack of confidence in the domestic currency. The rarely use of risk prevention tools for exchange rate volatility, the risk from external volatility, and pressure on the exchange rate and Kip price in the market. Meanwhile, the high demand for foreign currency in the market caused the over demand of USD lending and Thai Baht landing, which could be harmful to the Kip price stabilizing.

- A common use of foreign currency and cash payment in the domestic market, that is a consumer preference in Lao society. Moreover, the cash-based consumption habits in Laos caused the huge amount of Kip and 
reducing the effectiveness of monetary policy.

- Foreign capital outflow and the shortage of FX could cause the unconfident to domestic currency and brought the shock to the monetary and financial system (Gottschalk, 2014).

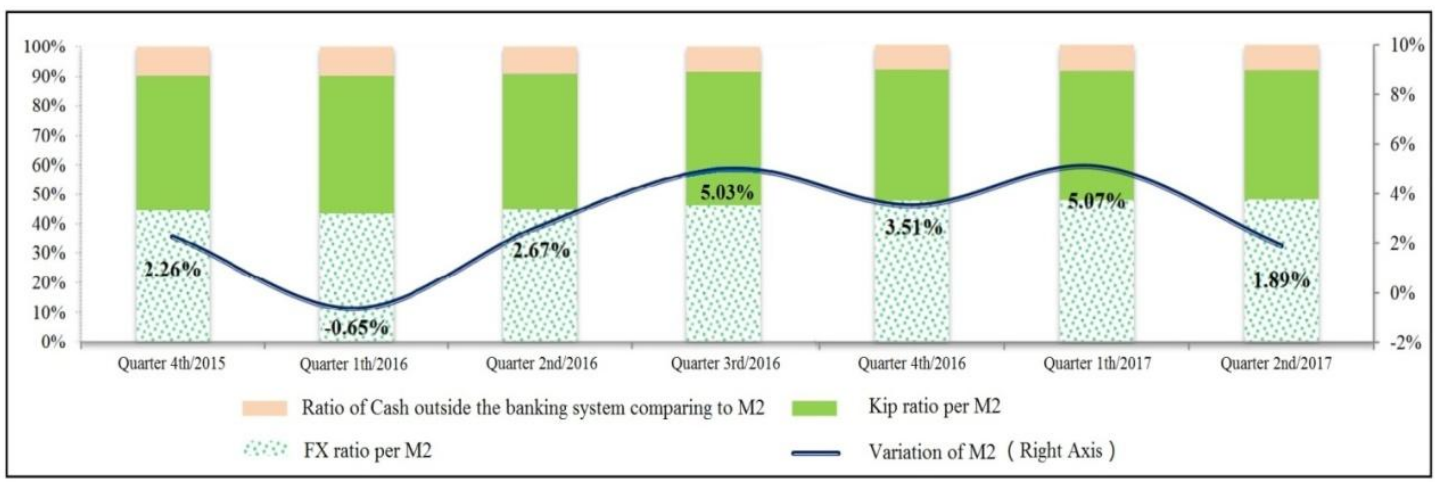

Figure 6. The money supply(M2) from the Quarter 4th/2015-Quarter 2nd/2017

Source: The bank of Lao PDR: Monetary statistic report of 2016 and 2017.

\subsection{Addressing Solution}

The challenges of the monetary policy implementing could cause the risk to the stable of Lao monetary system, inflation risk, obstruct the economic growth and stability. The existing studies (Bhattacharya, 2014; Lacker, 2014; Steiner, 2015; Srithilat, 2017), the BOL strategy (2016), the document IV of the IMF (2016) and the relating monetary policy theories. Plussing the actual implementation experience from the operation department. From the above knowledge, the appropriate addressing solution of the monetary policy implementation challenge integrated as follow:

- The policy authority has played attention on developing the money market condition, increasing and improving the market instruments, for instance, operated the Inter-bank money market in the end of 2016, the forex auctions to commercial banks and other forex derivatives such as forward contract, FX Swaps, future contract, and options. They mainly support the monetary policy implementing framework. Meanwhile, the BOL operating the Primary market and the Secondary market for auction, sale, repurchase, and trading the BOL bonds and Government bonds to the commercial bank and financial institutions.

- To address the Dollarization and multiple currencies consumption in the domestic market, promoted the use of domestic currency. The IMF report (2014) suggested to the authority to maintain the stability of domestic currency exchange rate by preserving Kip price and stabilizing the foreign exchange. In this decade, the authority expects that exchange rate stability or minimum appreciation/ depreciation. The exchange rate regime has been implemented by setting the daily reference exchange rate and relevant regulations. The commercial bank exchange rate gap sets at $\pm 2.5 \%$ for USD, $\pm 5 \%$ for Thai Baht and other currencies. In somehow the parallel market exchange rate much higher or lower than reference exchange rate caused by the high demand of USD (Dollarization) or Thai Baht in the domestic market. Somehow, the authority might use the market operation instrument such as the trading within Inter-Bank Market to adjust the money supply in Kip or Foreign currencies. The action intent to maintain the low float of exchange rate or adjust the rate in the parallel market getting closer to the reference rate. As The authority revealed, the effectiveness of exchange rate regime assisted the monetary policy implementing. The Presidential Decree Law No.01/P on "Governing the Management of Foreign Exchange and Precious Metals" is an important instrument for limit the use of foreign currencies, promoting the use of Kip in Lao market, reinforce related regulation for exchange rate and foreign currency management. The exchange rate float influences to the inflation variance and the effectiveness of monetary policy.

The authority introduced the Ad-Hoc interest rate policy which implemented by the commercial banks for the lower cost of Lao Kip lending, promoting the Kip credit increasing (IMF, 2015). In recent year, the policy authority appropriate adjusted by slowly decrease the central bank benchmark interest rate or commercial bank interest rate for support the economic growth.

- To address the cash payment in Kip and multiple currencies consumption in cash, the authorities also 
promoted Lao society to use the banking system for saving, rather than keeping large sums of cash assets outside the financial system. Meanwhile, authorities develop the payment system of domestic currency and FX, issuing cash transaction regulations, currency management regulations and additional instructions.

- The authority employs the International Transaction Reporting System to frequently track the Kip and FX cash inflow and outflow, estimate and forecast the quantity of incoming and outgoing cash flow to avoid the impact on leverage and stability of the system (BOL Strategy, 2016).

\section{Conclusion Remark}

This article has described monetary policy tools, implementation structure, and mechanism of the Lao PDR, which concluded the policy design, adjusting, decision and operation. The paper has also presented effective tools that used by policy authorities including the open market operation, interest rate management and capital raising, reserve requirement, the exchange rate, cash flow management, balancing of deposit and lending ratio and enforcement of relevant regulations. The BOL was presented as the implementer of the national monetary policy operating to reach ultimate objects such as maintaining low inflation rates, maintaining the steady value of the Lao Kip and exchange rate, and maintaining monetary stability to achieve robust growth of the national economy.

The descriptive analysis has been applied to the monetary policy implementation challenge and the addressing solutions studied. It The author applied descriptive analysis on the monetary policy implementation challenge and the appropriate solutions analysis. Based on the described of the Lao monetary policy implementation mechanism, the policy instruments and the actual policy operation situation. Plussing the monetary policy theories, literature studied, and practical experience of the implementors. The analysis has found the implementation challenges such as the limit of money market which obstructed the implementation of market operation; the dollarization and multiples currencies consumer preference; the risk of the exchange rate, challenged in Kip prices, and Kip lending; the foreign capital outflow challenge. Afterward, the paper focuses on the challenges addressing to ensure the monetary policy implementation effectiveness, preserve the monetary system stabilizing, promote stable development and long-term economic growth and be a significant reference for the policy authority in the futures.

\section{References}

Ageno, P. R., \& Pereira da Silva, L. A. (2014). Macroprudential regulation and the monetary transmission mechanism. Journal of Financial Stability, 13, 44-63. https://doi.org/10.1016/j.jfs.2014.02.002

Bank of Lao PDR. (2016). Lao Strategic Financial System Development Plan 2016-2025 and Vision toward 2030. The Decree No 316/Lao Government 19 August 2016

Bank of Lao PDR. (2017). Monetary Statistic Quarterly Report Q1/ 2017. Retrieved from https://www.bol.gov.la/together_use/Monetary Statistics Report Q1.2017.pdf

Banking Institue, Bank of Lao PDR. (2013). Financial Market. Vientiane: Banking Institue Press.

Bhattacharya, R. (2014). Inflation dynamics and monetary policy transmission in Vietnam and emerging Asia. Journal of Asian Economics, 34, 16-26. 1. https://doi.org/10.1016/j.asieco.2014.05.001

Decree-Law No.5. (1995). The Bank of Lao PDR. Issue Date: 14.10.1995

Gottschalk, J. (2014). Monetary policy frameworks: Financial Programming and Policies, Lao PDR. International Monetary Fund Training Material, May 5th-16th, 2014.

IMF. (2017). The Lao PDR Staff Report For The 2016 Article IV. IMF Country Report No.17/53

Khan, H. B., Ahmad, R. B., \& Gee, C. S. (2016). Bank competition and monetary policy transmission through the bank lending channel: Evidence from ASEAN. International Review of Economics and Finance, 44, 19-39. https://doi.org/10.1016/j.iref.2016.03.003

Kyophilavong, P. (2007). Monetary and exchange rate policies in the Lao PDR, Monetary and Exchange Rate Policies in Cambodia, Laos, and Vietnam. The Scope for Regional Cooperation Workshop, Finalization Report of The Asian Development Bank.

Kyophilavong, P. (2009). Evaluation of Macroeconomic Policy in Laos. Economic Research Center Discussion Paper No.171

Ma, Y., \& Lin, X. K. (2016). Financial development and the effectiveness of monetary policy. Journal of Banking \& Finance, 68, 1-11. https://doi.org/10.1016/j.jbankfin.2016.03.002 
Merrouche, O., \& Nier, E. (2017). Capital inflows, monetary policy, and financial imbalances. Journal of International Money and Finance, 77, 117-142. https://doi.org/10.1016/j.jimonfin.2017.05.004

Srithilat, K., \& Sun, G. (2017). The Impact of Monetary Policy on Economic Development: Evidence from Lao PDR. Global Journal of Human Social Science(E), 18(2), 8-15. Retrieve from https://mpra.ub.uni-muenchen.de/79369/

Steiner, A. (2017). Central banks and macroeconomic policy choices: Relaxing the trilemma. Journal of Banking and Finance, 77, 283-299. https://doi.org/10.1016/j.jbankfin.2015.07.005

Toshihisa, T., \& Kyophilavong, P. (2007). Unfavorable Truth of Currency Integration: The Case of Lao. JSPS working paper No.19530228

Yang, L., \& Hamori, S. (2016). Hot money and business cycle volatility: Evidence selected Asian Countries. Emerging Market Finance and Trade, 55(2), 351-363. https://doi.org/10.1080/1540496X.2015.1047302

\section{Copyrights}

Copyright for this article is retained by the author(s), with first publication rights granted to the journal.

This is an open-access article distributed under the terms and conditions of the Creative Commons Attribution license (http://creativecommons.org/licenses/by/4.0/). 